\title{
Bilişsel Davranışçı Yaklaşım Temelli Psiko-eğitim Programının Anneler Üzerindeki Etkililiğinin İncelenmesi*
}

\author{
Hanife PEHLIVAN ${ }^{* *}$
}

\begin{abstract}
Öz
$\mathrm{Bu}$ araştırmanın amacı, bilişsel davranış̧̧ yaklaşıma (BDY) dayalı psiko-eğitim programının kadın danışma merkezine başvuran annelerin problem çözme ve iletişim becerilerine, evlilik doyum ve iyi oluş düzeylerine etkisini incelemektir. Araştırma, Bornova Belediyesi Kadın Danışma Merkezi'ne aile içindeki sorunlarla başa çıkamama nedeniyle psikolojik yardım almak için başvuran annelerle yürütülmüştür. Araştırmada, $17^{\prime}$ si deney 1, 16's1 deney 2 ve $16^{\prime}$ 's kontrol grubunda olmak üzere toplam 49 denekle çalışılmış olup, bu denekler deney ve kontrol gruplarına rastgele atanmıştır. Her gruba ön test olarak Problem Çözme Envanteri, İletişim Becerileri Değerlendirme Ölçeği, Evlilik Yaşam Ölçeği ve Psikolojik İyilik Hali Ölçeği uygulanmıştır. Deney grubu her oturumu iki buçuk saat süren ve 16 oturumdan oluşan BDY'ye dayalı psikoeğitim programına tabi tutulmuştur. Kontrol grubuna ise herhangi bir müdahalede bulunulmamıştır. Uygulama bitiminde her iki gruba son test olarak aynı ölçekler tekrar uygulanmıştır. Ön test, son test uygulamalarından elde edilen veriler, karışık desenlerde kullanılması uygun bir teknik olan " $3 \times 2$ Karışık Desen ANOVA" tekniğiyle analiz edilmiştir. Araştırmada tüm analizler için anlamlılık düzeyi .05 olarak alınmıştır. Analizler sonucunda, BDY'ye dayalı psiko-eğitim programının annelerin problem çözme ve iletişim becerilerini, evlilik doyum ve iyi oluş düzeylerini artırdı ğı ortaya çıkmıştır.
\end{abstract}

Anahtar kelimeler: psiko-eğitim, problem çözme, iletişim becerileri, bilişsel davranış̧̧ı yaklaşım, evlilik doyumu, iyi oluş.

\footnotetext{
* Bu makale, Bilişsel Davranışçı Yaklaşıma Dayalı Psiko-eğitim Programının Kadın Danışma Merkezine Başvuran Annelerin İyi Oluş Düzeyi, Evlilik Doyumu, Problem Çözme ve İletişim Becerilerine Etkisi adlı doktora tezinin bir özetidir.

** Öğr. Gör. Dr., Ege Üniversitesi Eğitim Fakültesi, hanife.pehlivan@ege.edu.tr
} 
Ege Eğitim Dergisi 2014 (15) 1: 338-357

\title{
Investigation of The Effectiveness of A Psychoeducation Program
}

\section{Based Upon The Cognitive Behavioral Approach on Mothers}

\begin{abstract}
The aim of this research was to test the effects of the psycho-education program based on cognitive behavioral approach (CBA) on problem solving skills, communication skills, levels of marriage satisfaction and psychological wellbeing of the mothers who applied to get psychological help from Bornova Municipal Woman Counseling Center. The research was carried out with mothers who applied to Bornova Municipal Woman Counseling Center in order to handle their problems within the family. 49 subjects were randomly assigned to two groups: 33 subjects in the experimental group, and 16 subjects in the control group. Problem Solving Inventory, Communication Skills Evaluation Scale, Marriage Life Scale, and Psychological Well-Being Scale were administered to both groups as pretest. The psycho-education program, consisted of 16 sessions, based on CBA was applied to experimental group. After implementing the psycho-education program, the same scales were administered to both groups as posttest. The data obtained from both pretest and posttests were analyzed by the " $3 \times 2$ Complex Design ANOVA" technique which is suitable for complex designs. For all the analyses the level of significance has been taken as .05 . As a result of the analyses, it was found out that the psycho-education program based on CBA increased the mothers' problem solving skills, communication skills, levels of marriage satisfaction and psychological well-being.
\end{abstract}

Key words: psycho-education, problem solving, communication skills, marriage satisfaction, psychological well-being, cognitive behavioral approach. 



\section{Giriş}

Dünyada, kadınlar erkeklere göre pek çok açıdan hala dezavantajlı durumdadır. Okuma yazma bilmeyenlerin üçte ikisini kadınlar oluşturmakta, eğitimin her kademesinden kız çocukları daha az faydalanmakta, üniversiteye gitme şansına sahip kadınların büyük bir kısmı kadın meslekleri olarak bilinen sağlık ve eğitimle ilgili mesleklere özel olarak yönlendirilmektedir. Kadınların \% 60'a yakını hayatlarında en az bir kez fiziksel şiddete maruz kalmaktadır. Ücretli veya ücretsiz toplam çalışma süresi erkeklere göre çok daha uzun olmasına rağmen, yoksulluk oranları erkeklere göre çok yüksek olup, karar verici konumlarda bulunma oranları ise çok daha düşüktür (United Nations Statistics Division [UNSD], 2010). Bu nedenlerden ötürü her yaş grubundan kadın, ılımlı düzeydeki psikolojik ve fiziksel rahatsızlıkları daha fazla yaşamakta, psikolojik hizmet veren kurumlara çok daha fazla başvurmaktadır (Koopmans ve Lamers, 2007; Möller-Leimkühler, 2002; Türkiye İstatistik Kurumu [TÜIK], 2010). Ancak, gelişmekte olan diğer ülkeler gibi Türkiye'de de bu kadınların sadece \% 10'u yardım alabilmekte, \% 90' 1 yetersiz yardım almakta veya hiçbir şekilde yardım alamamaktadır (World Federation for Mental Health [WFMH], 2010).

Kadınlar psikolojik hizmet sunan kurumlara başvurduklarında, en fazla eşleriyle ve çocuklarıyla ilişkilerinde yaşadıkları sorunları (ailevi sorunlar) ve bu sorunların yol açtığı psikolojik rahatsızlıkları (depresyon) dile getirmektedir (Güleç, Yenilmez ve Ay, 2011; TÜİK, 2010). Çalışan veya çalışmayan tüm kadınların birincil sorumluluk alanlarının ev işi ve çocuk bakımı olması ve statülerinin düşük olması, kadınların ailevi sorunlar nedeniyle yardım kurumlarına başvurmalarına yol açmaktadır. Kadınların mevcut problem çözme ve iletişim becerileri, yaşadıkları sorunları etkili bir şekilde çözmede yetersiz kalmaktadır.

Problem çözme ve iletişim becerilerindeki eksiklikler her yaştan insanda çeşitli duygusal ve davranışsal sorunlara yol açmaktadır. Yapılan araştırmalarda, beceri eksikliğinin yetişkinlerde kaygı bozuklukları ve depresyonu (Kant, D'Zurilla ve Maydeu-Olivares, 1997), saldırganlığı (Arslan, 2010), kişilik bozukluklarını (Mcmurran, Egan, Blair ve Richardson, 2001), borderline kişilik bozukluğunu (Bray, Barrowclough ve Lobban, 2006), yeme bozuklukların (Fitzsimmons ve Bardone-Cone, 2011), psikotik bozuklukları (O'Brien ve diğerleri, 2009) ve Hipokondriak bozukluğu (Buwalda, Bouman, Marijtje ve Duijn 2006) artırdığı, yaşam doyumunu ise azalttığı (Chang, Sanna, Riley, Thornburg, Zumberg ve Edwards, 2007) ortaya çıkmışır. Ayrıca problem çözme ve iletişim becerileri yeterli olmayan yetişkinlerin ana babalık becerileri 
Bilişsel Davranışçı Yaklaşım Temelli Psiko-eğitim Programının Anneler Üzerindeki Etkililiğinin İncelenmesi

yeterince gelişmediği için çocuklarını istismar ve ihmal etme olasılığı da yükselmektedir (Corcoran, 2000). İstismara ve ihmale maruz kalan çocukların problem çözme becerileri düşük olup bu çocuklarda kaygı, depresyon, saldırganlık ve içedönüklük gibi her türden davranış sorunları daha fazla ortaya çıkmaktadır (Ethier, Lemelin ve Lacharite, 2004). Problem çözme becerileri yüksek olan yetişkinlerin ise kişiler arası ilişkileri oldukça iyidir ve bu durum onların psikolojik iyilik oluş düzeylerini olumlu yönde etkilemektedir (Chang ve diğ., 2007; Segrin ve Taylor, 2007). Benzer şekilde, evlilik doyumları da daha yüksektir (Eğeci ve Gençöz, 2006; Güven, 2005) ve evlilik doyumlarının yüksek olması, onların psikolojik ve fiziksel sağlıklarının daha iyi hale gelmesine neden olmaktadır (Kiecolt-Glaser, McGuire, Robles ve Glaser, 2002; Robles ve Kiecolt-Glaser, 2003; Waite Luo ve Lewin, 2009). Evlilik doyumunun düşük olması ise ailede psikopatolojinin ve diğer sağlıksız yapıların ortaya çıkmasında en büyük risk faktörünü oluşturmaktadır (Hahlweg ve Richter, 2010).

Söz konusu araştırmaların bulguları, ailede problem çözme-iletişim beceri düzeyi ve evlilik doyum düzeyi düşük bir annenin olmasının, hem annenin kendisi açısından hem ailede yaşayan diğer bireyler açısından ciddi risk içerdiğini ortaya koymaktadır. Annenin ailedeki diğer bireyleri etkilemesinin nedeni ev işi, çocuk bakımı ve ev içi ilişkileri düzenlemenin birincil olarak annenin sorumluluğunda olması, ailenin bir sistem olması ve sistemin öğelerinin birbirlerini döngüsel bir şekilde sürekli olarak etkilemesinden kaynaklanmaktadır (Gladding, 1998; Jackson, 1981; Minuchin, 1974; Satir, 1981; Steinglass, 1987). Dolayısıyla annelerin problem çözme-iletişim becerilerini ve evlilik doyumunu artırmak, söz konusu değişkenlerin düşük olmasının sonuçların iyileştirmekten daha önemlidir. Diğer bir deyişle problem çözmeiletişim becerilerinin ve evlilik doyumunun annede ve ailenin diğer bireylerinde neden olduğu depresyon vb. hastalıkları tedavi etmek, depresyon vb. hastalıkların ortaya çıkmasını önlemekten her anlamıyla çok daha maliyetlidir. Bu nedenle, yardım kurumlarına bu türden sorunlarla başvuran anneler için öncelikle yapılması gereken şey, problem çözme-iletişim becerilerini ve evlilik doyum düzeyini artırmaya yönelik etkili programlar geliştirmek ve bu programları uygulamaktır.

Problem çözme ve iletişim becerilerini, evlilik doyum düzeyini artırmaya yönelik geliştirilmiş çok sayıda psiko-eğitim programı vardır. Bu programların büyük bir kısmı BDY'a dayalı olarak hazırlanmaktadır. Bunun nedeni, BDY'nin yardım almak için başvuranlara yönelik eğitime dayalı, problem odaklı, hedef yönelimli ve uygulama süresi belirli olan bir terapi modeli önermesidir (Beck, 2001). Psiko-eğitim programlarında da benzer şeyler hedeflenir. Psiko-eğitim 
programları üzerine çalışan araştırmacılar, geçmişi keşfetmek yerine probleme odaklanırlar ve insanların etkili bir şekilde işlevde bulunmaları için belirli yaşam becerilerini öğrenebileceklerine vurgu yaparlar (Gazda, Ginter ve Horne, 2000).

Yapılan çalışmalar, BDY'a dayalı psiko-eğitim programlarının bazı sınırlılıkları olmasına rağmen katılımcı ana babalara çeşitli beceriler kazandırdığını, ana babaların bu becerileri kullanarak evlilik çatışması, depresyon, dikkat dağınıklı̆ı ve hiperaktivite gibi problemlerle daha etkili başa çıktıklarını ortaya koymuştur (Feinberg ve Kan, 2008; Hahlweg ve Richter, 2010; Maughan Christiansen, Jenson, Olympia ve Clark., 2005; Malouff, Thorsteinsson ve Schutte, 2007; Pihet, Bodenmann, Cina, Widmer ve Shantinath, 2007). Bu programların bazıları sadece bir amaca yönelik tek modüllü olarak hazırlanırken, bazılarında birkaç modül bir arada bulunmaktadır. Ailenin bir sistem olması ve aile içindeki problemlerin tek bir nedeninin olmamasından dolayı ana babalara yönelik hazırlanan programların birkaç boyutunun olması gerektiğini düşünen araştırmacılar (Nixon, 2002) çok modüllü programlara yönelmektedir. Hazırlanan bu programların içeriği, hedef grubun ihtiyacına göre BDY'ın problem çözme ve iletişim becerileri eğitimi, kendine yönerge verme, bilişsel yeniden yapılandırma, olumlu ana babalık uygulamaların artırma, evlilikle ilgili inançlarını ve beklentilerini fark etme ve irrasyonel düşüncelerini değiştirme gibi bazı müdahale yöntemleri bir araya getirilerek oluşturulur.

Türkiye'de sayıları giderek artmaya başlayan Kadın Danışma Merkezleri (KDM), özellikle sosyo-ekonomik düzeyi düşük olan kadınların ücretsiz olarak psikolojik hizmet alabilmek amacıyla başvurdukları yerlerdir. Kadınlar bu merkezlere, genellikle eşleriyle ve çocuklarıyla olan problemlerle baş edemediklerini ifade ederek başvurmaktadır. Ancak merkezlerin kurumsal kimliğinin henüz oluşmamasından, fiziksel koşullarının yetersizliğinden, çalışanların sayısının az olmasından ve kadınlarla çalışma konusunda uygun ve yeterli formasyona sahip olmamalarından kaynaklı olarak, verilen hizmetlerin çok yetersiz olduğu ve kadınların ihtiyaçlarını karşılamadığı görülmektedir. Merkezlerde, diğer eksikliklerin yanı sıra kadınlara grup halinde uygulanabilecek, kadınların problem çözme ve iletişim becerilerini, evlilik doyum ve iyi oluş düzeylerini artırmaya yönelik herhangi bir müdahale programi yoktur.

$\mathrm{Bu}$ araştırmada, KDM'ne başvuran annelerin problem çözme ve iletişim becerilerini, evlilik doyum ve iyi oluş düzeylerini artırmaya yönelik BDY'a dayalı bir psiko-eğitim programı geliştirmek ve programın problem çözme ve iletişim becerilerini, evlilik doyum düzeylerini artırmada etkili olup olmadığını 
Bilişsel Davranışçı Yaklaşım Temelli Psiko-eğitim Programının Anneler Üzerindeki Etkililiğinin İncelenmesi 343 değerlendirmek hedeflenmiştir. Ayrıca hazırlanan programın dolaylı bir şekilde annelerin iyi oluş düzeylerini yükseltmede etkili olup olmadığına da bakılmıştır.

\section{Yöntem}

\section{Araştırmanın Deseni}

Araştırmada ön test, son test uygulamalı, deneysel desen kullanılmıştır. Grup üyelerinden, uygulanan programın etkisini ölçmek amacıyla, uygulamadan önce ve uygulamadan sonra olmak üzere iki kez veri toplanmıştır.

\section{Deney ve Kontrol Grupları}

Araştırma deseni kapsamındaki deney ve kontrol grupları, Bornova Belediyesi KDM'ne aile içindeki sorunlarla başa çıkamama nedeniyle psikolojik yardım almak için başvuran annelerden oluşturulmuştur. Öncelikle, başvuran annelerle ön görüşme yapılmış, annelerin yardım talebinde bulunduğu sorun alanlarının hazırlanan psiko-eğitim programının içeriğine uygun olup olmadığı uygulayıcı tarafından değerlendirilmiştir. Ardından, psiko-eğitim grubuna katılması uygun görülen annelere psiko-eğitim programı anlatılmış ve söz konusu bu programdan yararlanabilecekleri yönünde tavsiyede bulunulmuştur. Gruba katılmayı kabul eden 54 danışanın 36'sı deney grubuna, 18'i kontrol grubuna seçkisiz olarak atanmıştır. Deney grubuna katılan 36 danışandan biri 20 ve diğeri 16 kişilik olmak üzere iki ayrı deney grubu oluşturulmuştur. Uygulama sürecinde 3 danışan birinci deney grubundan, 2 danışan da kontrol grubundan çeşitli nedenlerle ayrılmıştır. Araştırma, 33'ü deney grubuplarında, 16's1 kontrol grubunda olmak üzere toplam 49 denekle tamamlanmıştır.

Denekler yaş, eğitim düzeyi ve gelir düzeyi değişkenleri açısından incelenmiştir. Analizler sonucunda deneklerin \% 24,5'inin (12) 20-29, \% 59,2'sinin (29) 30-39, \%16,3'üuün (8) 40-49 yaş aralığında olduğu görülmüştür. Deneklerin \% 57,1'i (28) ilkokul, \% 16,3'ü (8) ortaokul, \% 14,3'ü (7) lise ve \% 12,2 'si ise (6) üniversite mezunudur. Deneklerin gelir düzeyine bakıldığında ise \% 4,1'inin (2) ortanın biraz üzerinde, \% 67,3'ünün (33) orta düzeyde, \% 24,5'inin (12) ortanın altında ve \% 4,1'inin (2) en düşük gelir düzeyine sahip olduğu görülmüştür.

Psiko-eğitim programının başlamasından bir hafta önce deney ve kontrol gruplarıyla bir oturum düzenlenmiştir. Oturumda, ön testler uygulanmış, program süresi belirtilmiş, psiko-eğitim programının ayrıntılı içeriği ve grup 
kuralları anlatılmıştır. Kontrol grubundaki danışanlara ise kendilerinin bekleme listesinde yer aldıkları, deney gruplarının oturumları bittikten sonra deney grupları için hazırlanan psiko-eğitim programına dâhil olabilecekleri belirtilmiştir.

\section{Veri Toplama Araçları \\ Problem Çözme Envanteri (PÇE)}

PÇE, 35 maddeden oluşan ve her maddesi 1-6 arasında derecelenen, likert tipi bir ölçektir. Bu envanter, Heppner ve Petersen tarafından 1982 yılında geliştirilmiştir. Ölçekten alınabilecek en düşük puan 32, en yüksek puan ise 192 'dir. Ölçekten alınan puanların yüksekliği bireylerin kendilerini problem çözme becerileri konusunda yetersiz olarak algıladıklarını göstermektedir. Ölçeğin güvenirlik çalışmasında Cronbach Alfa iç tutarlık katsayısı .90 olarak belirlenmiştir. Ölçeğin altı alt ölçeği bulunmaktadır. Bunlar; 1) aceleci yaklaşım, 2) düşünen yaklaşım, 3) kaçıngan yaklaşım, 4) değerlendirici yaklaşım, 5) kendine güvenli yaklaşım ve 6) planlı yaklaşımdır. Alt ölçekler için elde edilen katsayılar ise .72 ile .85 arasında değişmektedir. Ölçeğin Türkçe uyarlaması ise 1993 yılında Nail Şahin ve Nesrin Hisli Şahin tarafından gerçekleştirilmiştir.

\section{İletişim Becerilerini Değerlendirme Ölçeği (İBDÖ)}

Bireylerin iletişim becerilerini nasıl değerlendirdiklerini saptamak amacıyla Korkut (1996) tarafından geliştirilen 5'li likert tipi ölçek 25 ifadeden oluşmaktadır. Ölçekten alınabilecek en yüksek puan 125, en düşük puan ise 25 'tir. Elde edilen puanın yüksekliği bireylerin kendi iletişim becerilerini olumlu yönde değerlendirdikleri anlamına gelmektedir.

İBDÖ'nin güvenirlik çalışmasında test-tekrar test yöntemi kullanılmış, güvenirlik katsayısı .76 olarak bulunmuştur. Ölçeğin iç tutarlılığını saptamak amacıyla hesaplanan Cronbach Alfa iç tutarlılık katsayısı ise .80 olarak bulunmuştur.

\section{Evlilik Yaşam Ölçeği (EYÖ)}

Ölçek, eşlerin evlilik ilişkisinden sağladıkları genel doyum düzeylerini ölçmek amacıyla Tezer (1986) tarafından geliştirilmiştir. 10 sorudan oluşan 5'li likert tipi ölçekten alınabilecek en yüksek puan 50 , en düşük puan ise $10^{\prime}$ dur. Ölçeğin test-tekrar test yöntemi ile belirlenen güvenirlik kat sayısı .85, Cronbach Alfa iç tutarlılık katsayısı ise erkek grubunda .88, kadın grubunda .91 olarak bulunmuştur (Tezer, 1986). 
Bilişsel Davranış̧̧ı Yaklaşım Temelli Psiko-eğitim Programının Anneler Üzerindeki Etkililiğinin İncelenmesi

Psikolojik İyilik Hali Ölçeği (Scale of Psychological Well-being)

Ryff (1989) tarafından geliştirilen ölçek 84 maddeden oluşan, 5'li likert tipi bir ölçektir. Psikolojik İyilik Hali Ölçeğinin özerklik, çevreyle ilişkilerde hakimiyet kurma, kişisel gelişim, diğerleriyle olumlu ilişkiler kurma, yaşamdaki amaçlar ve kendini kabul etme olmak üzere altı alt ölçeği vardır ve her bir alt ölçekte 14 madde bulunmaktadır. Alt ölçeklerin güvenirlik ranjları .83 ile .91 arasında değişmektedir. Psikolojik iyilik hali ölçeği toplam puan veren bir ölçektir ve ölçekten yüksek puan almak kişinin psikolojik açıdan kendisini iyi hissettiğini göstermektedir (Cirhinlioğlu, 2006). Ölçeğin Türkçe 'ye uyarlanması Cirhinlioğlu (2006) tarafından gerçekleştirilmiştir.

\section{Kişisel Bilgi Formu}

Araştırmacı tarafından hazırlanan Kişisel Bilgi Formu'nda, deneklerin gelir durumu ve eğitim durumu gibi önemli olduğu düşünülen bazı sosyodemografik değişkenlerle ilgili sorular bulunmaktadır.

\section{Prosedür}

\section{Psikoeğitim Programının Geliştirilmesi}

$\mathrm{Bu}$ program, KDM'ne başvuran kadınların temel ihtiyaçları dikkate alınarak hazırlanmıştır. Örneklem grubunun tamamı dezavantajlı bölgede yaşayan (gecekondu bölgesi), sosyo-ekonomik statüsü düşük düzeyde olan ev kadınlarından oluşmaktadır. KDM'ne başvurma nedenleri ise eşleriyle ve çocuklarıyla yaşadıkları (ailevi sorunlar) sorunlarla baş edememeleridir. Bu bağlamda üç modüllü bir program hazırlanmıştır. Programın ilk modülünde annelerin çocuklarıyla yaşadıkları problemlerle başa çıkma becerilerini, ikinci modülünde iletişim becerilerini, üçüncü modülünde ise evlilik doyumlarını artırmaya yönelik müdahaleler yer almıştır.

1. Oturum: Grup üyelerinin birbirleriyle ve liderle tanışması. Grup kurallarının ve grup üyelerinin amaçlarının oluşturulması. Psiko-eğitim programının ve grup sürecinin kısaca gözden geçirilmesi.

2. Oturum: BDY'nin ilkelerini anlatma. Bu oturumda lider kişilik, kişilik gelişimi, biliş, şema, otomatik düşünce, duygu, davranış, işlevsiz düşünceler, sosyal öğrenme, koşullanma, pekiştirme gibi temel kavramların tanımını yapar. Lider bilişsel davranışçı kuramın ve bu kuramın kavramlarının bir kişiye uyarlanmasının örneği olarak Ayşe A. vakasını anlatır. Daha sonra katılımcılara bir olaya ilişkin düşünceleri, duyguları, davranışları ortaya 
çıkarmaya yardımcı olacak "Düşünce, Duygu, Davranış Kaydı Formu" nu tanıtır ve bu formu nasıl kullanacaklarını üyelere açıklar

3.,4. ve 5. Oturumlar: Okulöncesi, okul ve ergenlik dönemi çocuklarının normal gelişim özellikleri ve olası sorunlarını anlatma. Olası sorunlara BDY temelli çözüm önerileri sunma. Bu oturumlarda gözard1-teşvik, olumlu davranışı takdir etme, doğru şekilde ödüllendirme, token ekonomisi, ara verme, bedel ödetme, bilişsel yeniden yapılandırma gibi yöntemler, grup üyelerinin dile getirdikleri problemlerin çözümünde nasıl kullanacakları örnekler üzerinden anlatılmıştır ve üyelere bazı ödevler verilmiştir.

6. ve 7.Oturumlar: Aile içinde sık karşılaşılan problemlerin ifade edilmesini sağlama ve bu problemlerin çözümünde olumlu disiplin yöntemlerini uygulayabilme.

8., 9. ve 10.Oturumlar: İletişim becerilerini geliştirme. Bu oturumlarda pasif dinleme, aktif dinleme, ben dili ve empati gibi konulara yer verilir. Oturumlar boyunca lider her grup üyesini sorununu ben diliyle ifade etmesi için yönlendirir. Bu uygulama üyelerin iletişim becerilerinin grup içinde artmasını sağlayan yöntemlerden biridir.

11., 12. ve 13. Oturumlar: Evliliğin önemini kavrayabilme. Eşle yaşanan ilişkilerde ortaya çıkabilecek olası sorunları ifade etme. Cinsellik kavramını ve cinselliğe ilişkin öğrenmelerini BDY çerçevesinde gözden geçirme. Evlilikte cinsel yaşamdan beklentileri ifade etme. Cinsel yaşamı daha doyumlu hale getirmek için BDY'a dayalı yöntemleri uygulama. Bu oturumlarda grup üyelerinin evlilik ve cinselliğe ilişkin hatalı öğrenmeleri düzeltilir, gerçekçi olmayan inançları ve beklentileri sokratik sorgulama gibi yöntemlerle değiştirilmeye çalışılır.

14. ve 15. Oturumlar: Türk aile yapısını ve aile yaşam döngüsünü kavrayabilme. Aile yaşam döngülerinde ortaya çıkabilecek olası sorunları kavrayabilme. Bu sorunların çözümüne yönelik BDY'a dayalı yöntemleri uygulama.

16. Oturum: Değerlendirme: Grup sürecini ve kazanımları gözden geçirme. Grup sürecinde çözülemeyen problemler için yol haritası belirleme. Problemlerin nüksetmesi halinde yapılacaklar konusunda bilgilendirme. Vedalaşma.

\section{Psiko-eğitim Programının Uygulanması}

Psiko-eğitim programının uygulamasına başlamadan önce deney 1, deney 2 ve kontrol gruplarındaki deneklerin Problem Çözme Envanteri, İletişim Becerileri Değerlendirme Ölçeği, Evlilik Yaşam Ölçeği ve İyilik Hali Ölçeği'nden aldıkları puanların aritmetik ortalamaları ve standart sapmaları incelenmiş ve Tablo 1'de verilmiştir. Grupların ortalamaları arasında anlamlı düzeyde fark olup olmadığına tek yönlü varyans analizi ile bakılmıştır. 
Bilişsel Davranışçı Yaklaşım Temelli Psiko-eğitim Programının Anneler Üzerindeki Etkililiğinin İncelenmesi

Analizler sonucunda, deney ve kontrol gruplarının Problem Çözme Envanteri'nden, $\quad F(2,46)=1.33 \quad p=.27$, İletişim Becerileri Değerlendirme Ölçeği'nden $F(2,46)=1.00 p=.37$, Evlilik Yaşam Ölçeği'nden $F(2,45)=.33 p=.71$, İyilik Hali Ölçeği'nden $F(2,46)=2.00 \quad p=.14$, aldıkları puanların aritmetik ortalamaları arasında istatistiksel olarak anlamlı düzeyde fark bulunmamıştır. Diğer bir deyişle, deney 1 deney 2 ve kontrol gruplarında bulunan deneklerin deneysel işlemden önceki problem çözme ve iletişim becerileri, evlilik doyumu ve iyi oluş düzeyleri birbirine denk durumdadır.

Deney ve kontrol gruplarının birbirine denk olduğunun anlaşılmasının ardından hazırlanan psiko-eğitim programının uygulanmasına geçilmiştir. Deney grubunu oluşturan annelere her biri yaklaşık 2,5 saat süren ve 16 oturumdan oluşan BDY'a dayalı psiko-eğitim programı uygulanmıştır. Her hafta bir oturum yapılmış, oturumlar iki bölüm halinde gerçekleştirilmiştir. Oturumlarda 1 saat 15 dakikalık birinci bölümün ardından, 15 dakika ara verilmiş, aradan sonra 1 saat 15 dakika süren ikinci bölüm yapılmıştır. Oturumlar araştırmacının liderliğinde mesai saati içinde Bornova Belediyesi KDM'nin eğitim salonunda gerçekleştirilmiştir. Uygulama Şubat 2010'da başlamış, Haziran 2010 'da bitmiş ve uygulamadan bir hafta sonra katılımcılara son testler yapilmıştır.

Araştırmada toplanılan veriler SPSS 15.0 ile analiz edilmiştir. İstatistiksel analiz tekniği olarak “3×2 Karışık Desen ANOVA” tekniği kullanılmıştır.

\section{Bulgular}

Araştırmada hazırlanan psiko-eğitim programının annelerin problem çözme ve iletişim becerileri, evlilik doyumu ve iyi oluş düzeyleri üzerinde etkili olup olmadığını test etmek amacıyla, ön test son test ölçümlerinden aldıkları puanların ortalamaları arasında anlamlı düzeyde fark olup olmadığına bakılmıştır. Bunun için karışık ölçümler için üç faktörlü varyans analizi tekniği kullanılmıştır.

Tablo 1'de, deney ve kontrol gruplarının Problem Çözme Envanteri, İletişim Becerileri Değerlendirme Ölçeği, Evlilik Yaşam Ölçeği ve İyilik Hali Ölçeği ön test ve son test ölçümlerinden aldıkları puanların aritmetik ortalamaları, standart sapmaları verilmiştir. 
Tablo 1: Deney ve Kontrol Gruplarının Problem Çözme Envanteri, İletişim Becerileri Değerlendirme Ölçeği, Evlilik Yaşam Ölçeği, İyilik Hali Ölçeği Ön Test ve Son Test Ölçümlerinden Aldıkları Puanların Aritmetik Ortalamaları ve Standart Sapmaları

\begin{tabular}{|c|c|c|c|c|c|c|c|c|c|c|c|c|}
\hline & \multicolumn{12}{|c|}{ Grup } \\
\hline & \multicolumn{4}{|c|}{ Deney grubu 1} & \multicolumn{4}{|c|}{ Deney grubu 2} & \multicolumn{4}{|c|}{ Kontrol grubu } \\
\hline & \multicolumn{2}{|c|}{ Ön test } & \multicolumn{2}{|c|}{ Son test } & \multicolumn{2}{|c|}{ Ön test } & \multicolumn{2}{|c|}{ Son test } & \multicolumn{2}{|c|}{ Ön test } & \multicolumn{2}{|c|}{ Son test } \\
\hline & $\bar{X}$ & $S$ & $\bar{X}$ & $S$ & $\bar{X}$ & $S$ & $\bar{X}$ & $S$ & $\overline{\bar{X}}$ & $S$ & $\bar{X}$ & $S$ \\
\hline $\begin{array}{l}\text { Problem } \\
\text { çözme } \\
\text { bec. }\end{array}$ & 106.70 & 17.60 & 79.11 & 19.20 & 103.00 & 16.11 & 75.93 & 15.51 & 113.56 & 21.68 & 118.00 & 19.26 \\
\hline $\begin{array}{l}\text { İletişim } \\
\text { becerisi }\end{array}$ & 100.05 & 14.49 & 109.00 & 12.37 & 100.68 & 10.89 & 109.25 & 10.32 & 94.43 & 15.45 & 93.00 & 14.63 \\
\hline $\begin{array}{l}\text { Evlilik } \\
\text { doyumu }\end{array}$ & 32.18 & 8.87 & 39.62 & 8.08 & 32.68 & 8.24 & 40.18 & 6.91 & 30.31 & 8.86 & 28.25 & 8.69 \\
\hline $\begin{array}{l}\text { İyilik } \\
\text { hali }\end{array}$ & 161.76 & 16.38 & 190.88 & 12.76 & 166.56 & 15.06 & 193.37 & 19.27 & 155.00 & 17.73 & 149.75 & 15.43 \\
\hline
\end{tabular}

Yapılan analizlerde deney 1, deney 2 ve kontrol grubunun Problem Çözme Envanteri'nden aldıkları puanların zaman ve grup ortak etkisinin (grup*ölçüm) istatistiksel olarak anlamlı düzeyde olduğu bulunmuştur $F(2,46)=20.35 p=.00$, $\eta_{\mathrm{p}}{ }^{2}=.46$. Söz konusu ortak etkinin kaynağını araştırmak üzere, post-hoc analizi testlerinden bonferroni kullanılmıştır. Sonuçlara göre, deney 1 grubunun problem çözme puanlarının ortalaması, kontrol grubunun problem çözme puanlarının ortalamasından istatistiksel olarak anlamlı düzeyde düşük bulunmuştur $(p=.001)$. Benzer şekilde deney 2 grubunun problem çözme puanlarının ortalaması, kontrol grubunun problem çözme puanlarının ortalamasından istatistiksel olarak anlamlı düzeyde düşük bulunmuştur $(p=.00)$. Buna karşılık, deney 1 grubuyla deney 2 grubunun problem çözme puanlarının ortalaması arasındaki fark istatistiksel olarak anlamlı değildir $(p=.1 .00)$. Yine, yapilan analizlerde deney 1 , deney 2 ve kontrol grubunun İletişim Becerileri Değerlendirme Ölçeği'nden aldıkları puanların zaman ve grup ortak etkisinin (grup*ölçüm) istatistiksel olarak anlamlı düzeyde olduğu bulunmuştur $F(2,46)=7.72 p=.00, \eta_{\mathrm{p}}^{2}=.25$. Söz konusu ortak etkinin kaynağını araştırmak üzere, post-hoc analizi testlerinden bonferroni kullanılmıştır. Sonuçlara göre, deney 1 grubunun iletişim becerileri puanlarının ortalaması, kontrol grubunun iletişim becerileri puanlarının ortalamasından istatistiksel olarak anlamlı düzeyde yüksek bulunmuştur $(p=.05)$. Benzer şekilde deney 2 grubunun iletişim becerileri puanlarının ortalaması, kontrol grubunun iletişim becerileri puanlarının ortalamasından istatistiksel olarak anlamlı düzeyde yüksek bulunmuştur $(p=.04)$. Buna karşılık, deney 1 grubuyla deney 2 grubunun iletişim becerileri puanlarının ortalaması arasındaki fark istatistiksel olarak anlamlı değildir $(p=.1 .00)$. Yapılan analizlerde deney 1 , deney 2 ve kontrol grubunun Evlilik Yaşamı Ölçeği'nden aldıkları puanların zaman ve 
Bilişsel Davranışçı Yaklaşım Temelli Psiko-eğitim Programının Anneler Üzerindeki Etkililiğinin İncelenmesi

grup ortak etkisinin (grup*ölçüm) istatistiksel olarak anlamlı düzeyde olduğu bulunmuştur $F(2,45)=21.27 p=.00 \quad \eta_{\mathrm{p}}^{2}=.48$ Söz konusu ortak etkinin kaynağını araştırmak üzere, post-hoc analizi testlerinden bonferroni kullanılmıştır. Sonuçlara göre, deney 1 grubunun evlilik yaşamı ölçek puanlarının ortalaması, kontrol grubunun evlilik yaşamı ölçek puanlarının ortalamasından oldukça yüksek olmasına rağmen istatistiksel olarak anlamlı değildir $(p=.06)$. Deney 2 grubunun evlilik yaşamı ölçek puanlarının ortalaması, kontrol grubunun evlilik yaşamı ölçek puanlarının ortalamasından istatistiksel olarak anlamlı düzeyde yüksek bulunmuştur $(p=.04)$. Buna karşılık, deney 1 grubuyla deney 2 grubunun problem çözme puanlarının ortalaması arasındaki fark istatistiksel olarak anlamlı değildir $(p=.1 .00)$. Yapılan analizlerde deney 1 , deney 2 ve kontrol grubunun İyilik Hali Ölçeği'nden aldıkları puanların zaman ve grup ortak etkisinin (grup*ölçüm) istatistiksel olarak anlamlı düzeyde olduğu bulunmuştur $F(2,44)=.22 .32 p=.00 \quad \eta_{\mathrm{p}}{ }^{2}=.49$ Söz konusu ortak etkinin kaynağını araştırmak üzere, post-hoc analizi testlerinden bonferroni kullanılmıştır. Sonuçlara göre, deney 1 grubunun iyilik hali puanlarının ortalaması, kontrol grubunun iyilik hali puanlarının ortalamasından istatistiksel olarak anlamlı düzeyde yüksek bulunmuştur $(p=.00)$. Benzer şekilde deney 2 grubunun iyilik hali puanlarının ortalaması, kontrol grubunun iyilik hali puanlarının ortalamasından istatistiksel olarak anlamlı düzeyde yüksek bulunmuştur $(p=.00)$. Buna karşılık, deney 1 grubuyla deney 2 grubunun iyilik hali puanlarının ortalaması arasındaki fark istatistiksel olarak anlamlı değildir $(p=.1 .00)$. Yani yapılan analizler, deney 1 ve deney 2 gruplarına katılan annelerin problem çözme ve iletişim becerilerinin, evlilik doyumu ve iyi oluş düzeylerinin kontrol grubundaki annelerin problem çözme ve iletişim becerilerine, evlilik doyumu ve iyi oluş düzeylerine göre istatistiksel olarak anlamlı düzeyde yükseldiğini göstermiş̧tir.

\section{Tartışma}

$\mathrm{Bu}$ araştırmada, BDY'a dayalı psiko-eğitim programının KDM'ne başvuran annelerin problem çözme ve iletişim becerilerine, evlilik doyumu ve iyi oluş düzeylerine etkisi incelenmiştir. Araştırmadan elde edilen bulgular, hazırlanan psiko-eğitim programının annelerin problem çözme ve iletişim becerileri, evlilik doyum ve iyi oluş düzeylerini artırdığını ortaya koymuştur.

Psiko-eğitim programına katılan annelerin problem çözme ve iletişim becerilerindeki artışın nedenlerini anlamak için söz konusu programın ilk iki modülüne ve bu modüllerin uygulanma sürecine bakmak gerekir. Programın 
ilk iki modülünde, hem bireysel problem çözme ve iletişim becerilerini arttırmaya yönelik bilgilere, hem de annelerin ev içinde sık karşılaştıkları problemlerin çözümüne yönelik uygulamalara yer verilmiştir. Bu uygulamalarda öncelikle ev içinde sık karşılaşılan problemler tanımlanmış, daha sonra konuya ilişkin teorik bilgiler verilmiş, son olarak da problemlerin alternatif çözümleri üzerine tartışılmış ve annelere deneme niteliğinde öneriler sunulmuştur. Bir sonraki hafta ise sunulan önerilerin işe yarayıp yaramadığı tartışılmışır. Böylelikle, anneler probleme ilişkin çözümleri etkili bir şekilde öğrenmişlerdir. Ayrıca, aynı problemi yaşamış bir grup üyesinin, o probleme bulduğu çözümü de grup sürecinde dinlemişler, grup üyesini kendilerine model alarak benzer bir çözüm yöntemini kendileri de uygulamışlardır. Model alma süreci de annelerin beceri kazanmasını hızlandırmıştır. Bu bulgular, Kim, Hyun, Hong ve Choi'nin (2011), agresif çocukların annelerine yönelik hazırladıkları sosyal beceri eğitimi ve ebeveynlik eğitimi programlarının etkililiğini üç farklı grup üzerinde test ettiği araştırmanın; Brody, Murry, McNair Chen, Gibbons, Gerrard ve Wills'in (2005), kırsal kesimde yaşayıp risk altında olan, Afrika kökenli Amerikalı ergen anneleri için hazırladığı müdahale programinin; Rodrigo, Maiquez, Correa, Martin ve Rodriguez'in (2006), psikososyal açıdan risk altında bulunan annelere yönelik uyguladıkları psiko-eğitim programın etkilerini değerlendirdikleri araştırmanın bulgularıyla paralellik göstermektedir.

Psiko-eğitim programına katılan annelerin evlilik doyum düzeylerini artırmalarının nedenlerini anlamak için programın evlilik ilişkilerine ilişkin modülünün uygulanma sürecine bakmak gerekir. Evlilik ilişkileri modülünde öncelikle annelerin evlilik yaşamına ilişkin düşünceleri ve beklentileri ele alınmış, sorunlarını somutlaştırmaları sağlanmıştır. Daha sonra, evlilik doyumunu etkileyen etmenlere ilişkin teorik bilgiler verilmiştir. $\mathrm{Bu}$ bilgilendirme esnasında toplumsal cinsiyet rolleri, normal ve normal dışı cinsel davranışlar, geleneksel Türk aile yapısının özellikleri gibi konular BDY çerçevesinde anlatılmıştır. Genel olarak BDY, sorunlu davranışların hatalı bilişsel süreçlerden veya problemli öğrenme süreçlerinden kaynaklandığını; farklı öğrenme süreçleriyle sorunlu davranışların değiştirebileceğini veya yeni davranışların edinilebileceğini varsayar (Seligman, 2001). Bu modülde, diğer iki modülde olduğu gibi annelere, deneme niteliğindeki BDY'a dayalı çözüm yöntemleriyle veya bilgilendirme yoluyla farklı bir öğrenme süreci yaratılmıştır. Sürecin bu şekilde işleyişi, annelerin evlilik ilişkilerinde sorunları doğru bir şekilde tanımlamalarına ve bu sorunları daha etkili bir şekilde çözmelerine neden olmuştur. $\mathrm{Bu}$ bulgu, literatürdeki benzer araştırma bulgulariyla paraleldir (Canel, 2007; E. M. Cummings, Faircloth, Mitchell, J. S. Cummings ve Schermerhorn, 2008; Faircloth ve Cummings, 2008; Hahlweg ve 
Bilişsel Davranışçı Yaklaşım Temelli Psiko-eğitim Programının Anneler Üzerindeki Etkililiğinin İncelenmesi

Richter, 2010; Kalkan ve Ersanl1, 2008; Markman, Floyd, Stanley ve Storaasli,1988; Pihet ve diğ., 2007; Sardoğan ve Karahan, 2005).

$\mathrm{Bu}$ araştırmada iyi oluş düzeyini arttırmaya yönelik özel olarak hazırlanmış bir program modülü yoktur. Ancak ilgili literatür incelendiğinde, problem çözme ve iletişim becerileri ile iyi oluş düzeyi arasında pozitif yönde bir korelasyon vardır. Yani, problem çözme ve iletişim becerileri düzeyi yüksek olan kişilerin iyi oluş düzeyleri de daha yüksektir (Chang ve diğ., 2007; Segrin ve Taylor, 2007). Benzer şekilde, evlilik doyum düzeyi ile iyi oluş düzeyi arasında da bir korelasyon vardır. Yani, evlilik doyumu düzeyleri yüksek olan kişilerin iyi oluş düzeyleri de daha yüksektir (Eğeci ve Gençöz, 2006; Güven, 2006; KiecoltGlaser ve diğ., 2002; Robles ve Kiecolt-Glaser, 2003). Literatürde sözü edilen ilişkiden hareketle, bireylerin problem çözme ve iletişim becerilerini ve evlilik doyum düzeylerini artırmayı hedefleyen bir psiko-eğitim programının iyi oluş düzeylerini de artıracağı düşünülmüştür. Araştırmanın bulguları bu hipotezi destekler niteliktedir ve bu bulgu önemlidir. Çünkü iyi oluş kavramı en genel tanımıyla insanın psikolojik olarak optimal düzeyde işlev görmesidir ve geliştirilen psiko-eğitim programı, katılımcların psikolojik olarak optimal düzeyde işlev görmesine katkıda bulunmuştur. Yani, katılımcılar bu program sayesinde kendilerini daha fazla kabul etmişler, insanlarla ilişkileri daha iyi hale gelmiş, kontrol duyguları artmış ve yaşamda yeni amaçlar edinmişlerdir.

Genel olarak bu araştırmada üzerinde tartışılması gereken konulardan birisi, birkaç modülün bir arada kullanılması ve uygulama süresinin 16 hafta gibi uzun bir süreye yayılmasıdır. Modüllerin bir arada kullanılmasının sebebi, psiko-eğitim programına katılan annelerin aile içinde yaşadıkları problemlerle baş edemedikleri için yardım talebinde bulunmalarıdır. Literatürde belirtildiği gibi, aile içindeki problemlerin tek bir nedeni yoktur. Bu durum, ailenin bir sistem olmasından ve sistemin parçalarının birbirlerini döngüsel bir şekilde sürekli olarak etkilemesinden kaynaklanmaktadır (Steinglass, 1987). Bu nedenle, ana babalara yönelik hazırlanan programların birkaç boyutunun olması gerekmektedir. Böylelikle, daha fazla probleme çözüm bulunacaktır ve her bir modül odaklanılan problemin dışındaki problemlerin çözümünü de kolaylaştıracaktır (Bullard ve diğ., 2010; Nixon, 2002). Söz konusu araştırmanın bulguları da bu hipotezi destekler niteliktedir. Ancak birkaç modülün bir arada kullanılması, hangi modülün, hangi sorun alanında, ne kadar değişim yarattığı sorusunun yanıtsız kalmasına sebep olmaktadır. İleride yapılacak çalışmalarda bu sorunun dikkate alınması önem arz etmektedir. Araştırmada uygulama süresinin uzun olması belirlenen konuların ayrıntılı bir şekilde sunulmasına ve her bir katılımcının konuya ilişkin duygu ve düşüncelerini ifade etmesine olanak vermiştir. Literatürde, programı uygulama süresinin programın etkililiği 
üzerindeki etkisine ilişkin tartışmalı bulgular olsa da, genel eğilim uzun süreli programların etkililiğinin kısa süreli programların etkililiğinden daha yüksek olduğu yönündedir (Markman , Stanley, Jenkins, Petrella ve Wadsworth, 2006). Burada esas mesele, program süresinin uzun olmasının katılımcıların programı yarıda bırakmasına veya düzensiz devam etmesine yol açıp açmadığıdır. Ancak bu araştırmanın uygulama sürecinde sadece beş kişi programı yarıda bırakmıştır. Buradan hareketle, katılımcıların problemlerine uygun, iyi yapılandırılmış bir psiko-eğitim programının süresinin uzun olmasının katılımcıların programa devam etmesinde bir soruna yol açmadığı söylenebilir.

Araştırma sonucunda ortaya çıkan bulguları iyi anlamak için grup üyelerinin özelliklerine de bakmak gerekir. Psiko-eğitim programına katılanların tamamı dezavantajlı bölgede (gecekondu bölgesi) yaşamaktadır ve görece sosyoekonomik seviyeleri düşüktür. Ekonomik nedenlerden dolayı hiçbirisinin daha önce uzun süreli psikolojik yardım alma fırsatı olmamıştır. Yaşadıkları bölgede hizmet veren KDM'nde annelerin psikolojik ihtiyaçlarını karşılayacak uzun süreli bir psiko-eğitim programının ücretsiz olarak açılması, onların kendilerini değerli hissetmelerine yol açmış ve onları heyecanlandırmıştır. Bu nedenle, psiko-eğitim programına çok yüksek bir motivasyonla başlamışlardır. Bu durum, katılımcıların amaçlarına ulaşmasını hızlandırmış olabilir.

$\mathrm{Bu}$ araştırmanın bazı sınırlıkları vardır. Hazırlanan psiko-eğitim programının boylamsal etkisine bakılmamıştır. Programın etkisinin kalıcı olup olmadığını anlamak için ileride yapılacak araştırmalarda, katılımcıların üç ay, altı ay, 12 ay, beş yıl gibi belirli aralıklarla izlenmesi gerekmektedir. Ayrıca çalışmanın ilk olması nedeniyle geliştirilen psiko-eğitim programının etkileri başka çalışmalarla ve farklı gruplarla yeniden sinanabilir. Böylece, elde edilen bulguların genellenebilirliği test edilebilir. Ancak, programı uygulayacak uzmanların programın içeriğini çok iyi anlamaları, programla ilgili kuramsal bilgiye ve psiko-eğitim gruplarını yürütme becerisine sahip olmaları gerekmektedir.

Sonuç olarak bu araştırma, Türkiye' de önleyici ruh sağlığı merkezlerinden biri olma potansiyeli olan KDM'nde (bu merkezlerin kurumsal kimliği henüz oluşmamıştır) sosyo-ekonomik düzeyi düşük olan kadınların problem çözmeve iletişim becerilerini, evlilik doyum ve iyi oluş düzeylerini artırmaya yönelik yapılan ilk deneysel araştırma olması ve yapılacak araştırmalara model olması açısından önemlidir. Türkiye' de kadının aile içinde üstlendiği kilit rol, kadının statüsünün düşüklüğü ve psikolojik yardım alma ihtiyacı dikkate alınırsa araştırmanın önemi daha çok anlaşılacaktır. Problem çözme ve iletişim becerileri gelişmiş mutlu bir kadın kendi statüsünü güçlendirmek için daha çok 
Bilişsel Davranışçı Yaklaşım Temelli Psiko-eğitim Programının Anneler Üzerindeki Etkililiğinin İncelenmesi

çaba harcayacak, ailenin diğer üyelerinin de olumlu yönde değişmesine katkı sağlayacaktır. 


\section{Kaynakça}

Arslan, C. (2010). An investigation of anger and anger expression in terms of coping with stress and interpersonal problem-solving. Kuram ve Uygulamada Eğitim Bilimleri/Educational Sciences: Theory and Practice, 10(1), 25-43.

Beck, J. S. (2001). Bilişsel terapi: Temel ilkeler ve ötesi (1. Basım). Ankara. Türk Psikologlar Derneği Yayınları.

Bray, S., Barrowclough, C. ve Lobban, F. (2006). The social problem-solving abilities of people with borderline personality disorder. Behaviour Research and Therapy, 45, 1409-1417.

Brody, G. H., Murry, W. M., McNair Chen, Y., Gibbons, F., Gerrard, M. ve Wills, T. A. (2005). Linking changes in parenting to parent-child relationship quality and youth self-control: The strong African American families program. Journal of

Bullard, L., Wachlarowicz, M., DeLeeuw, J. Snyder, J., Low, S., Forgatch, M. ve DeGarmo, D. (2010). Effects of the oregon model of parent management training (PMTO) on marital adjustment in new stepfamilies: a randomized trial. Journal of Family Psychology, 24(4), 485-496.

Buwalda, F. M., Bouman, T. K., Marijtje, A. J. ve Duijn, V. (2006). Psychoeducation for hypochondriasis: a comparison of a cognitive-behavioural approach and a problem-solving approach. Behavioural Research and Therapy, 45, 887-899.

Canel, A.N. (2007). Ailede problem çözme, evlilik doyumu ve örnek bir grup çalı̧̧masının sınanması. (Yayınlanmamış doktora tezi). Marmara Üniversitesi Eğitim Bilimleri Enstitüsü, İstanbul.

Chang, E. C., Sanna, L. J., Riley, M. M., Thornburg, A. M., Zumberg, K. M. ve Edwards M. C. (2007). Relations between problem-solving styles and psychological adjustment in young adults: is stress a mediating variable? Personality and individual differences, 42, 135-144.

Cirhinlioğlu, F.G. (2006). Üniversite öğrencilerinde utanç eğilimi, dini yönelimler, benlik kurguları ve psikolojik iyilik hali arasındaki ilişkiler. Hacettepe Üniversitesi Sosyal Bilimler Enstitüsü, Ankara.

Corcoran, J. (2000). Family interventions with child physical abuse and neglect: A critical review. Children and Youth Services Review, 22(7), 563-591.

Cummings, E. M., Faircloth, B., Mitchell, B. M., Cummings, J. S. ve Schermerhorn A. C. (2008). Evaluating a brief prevention program for improving marital conflict in community families. Journal of Family Psychology, 22(2), 193-202.

Dünya Ruh Sağllğı Federasyonu (WFMH), (2007). The lancet series on global mental health. Temmuz 2011'de http://www.wfmh.org/'dan elde edildi. 
Bilişsel Davranış̧̧ı Yaklaşım Temelli Psiko-eğitim Programının Anneler Üzerindeki Etkililiğinin İncelenmesi

Ethier, L. S., Lemelin, J. P. ve Lacharite, C., (2004). A longitudinal study of the effects of chronic maltreatment on children's behavioral and emotional problems. Child Abuse \& Neglect, 28, 1265-1278.

Eğeci, İ.S. ve Gençöz, T. (2006). Factors Associated with relationship satisfaction: important of communication skills. Contempt Fam Ther, 28, 383-391.

Faircloth, W. B. ve Cummings, E. M. (2008). Evaluating a parent education program for preventing the negative effect of marital conflict. Journal of Applied Developmental Psychology, 29, 141-156.

Feinberg, M. E. ve Kan, M. L. (2008). Establishing family foundations: impact of a transition to parenting program on coparenting, depression, parent-child relatiponship and infant regulation. Journal of Family Psychology, 22, 253-263.

Fitzsimmons, E. E. ve Bardone-Cone, A. M. (2011). Coping and social support as potential moderators of the relation between anxiety and eating disorder symptomatology. Eating Behaviors, 12, 21-28.

Gazda, G.M, Ginter, E.J \& Horne, A.M (2000). Group counseling and psychotherapy: Theory and application (first ed.). Boston. Allyn and Bacon.

Gladding, S. T. (1998). Family therapy: history, theory, and practice. (Second ed.). New Jersey. Prentice-Hall.

Güleç, G. Yenilmez, Ç. ve Ay, F. (2011). Bir Anadolu şehrinde psikiyatri kliniğine başvuran hastaların hastalık açıklama ve çare arama davranışları. Klinik Psikiyatri, 14, 131-142.

Güven, N. (2005). İlişkilerle ilgili bilişsel çarpıtmalar ve evlilikte problem çözme becerilerinin evlilik doyumu ile ilşkisi. (Yayınlanmamış yüksek lisans tezi). Ankara Üniversitesi Eğitim Bilimleri Enstitüsü, Ankara.

Hahlweg, K. ve Richter, D. (2010). Prevention of marital instability and distress. Result of an 11-year longitudinal follow-up study. Behavior research and therapy, 48, 377-383.

Jackson, D. D. (1981). Family Rules: marital quid pro quo. İçinde G.D. Ericson, T.P. Hogan (Ed.). Family Therapy: An Introduction to Theory and Technique (2nd ed.), (pp. 16-23). California: Brooks/Cole Publishing Company.

Kant, G.L., D'Zurilla T. ve Maydeu-Olivares A. (1997). Social problem solving as a mediator of stres-related depression and anxiety in middle-aged and elderly community residents. Cognitive therapy and research, 21(1), 73-96.

Kalkan, M. ve Ersanlı, E. (2008). Bilişsel davranışçı yaklaşıma dayalı evlilik ilişkisini geliştirme programının evli bireylerin evlilik uyumuna etkisi. Kuram ve Uygulamada Ĕ̆itim Bilimleri, 8, 963-986.

Kiecolt-Glaser, J. K., McGuire, L., Robles, T. F. ve Glaser, R. (2002). Emotions, morbidity and mortality. New perspective psyconeuroimmunology. Annu Rev. psycho, 53, 83-107. 
Kim M., Hyun S., Hong J. S. ve Choi M. (2011). Social skills train and parent education programs for aggressive preschoolers and their parents in South Korea. Children and Youth Services Review, 33, 838-845.

Koopmans, G. T. ve Lamers, L. M. (2007). Gender and healh care utilization: the role of mental distress and help-seeking propensity. Social Science $\mathcal{E}$ Medicine, 64, 1216-1230.

Malouff, J. M., Thorsteinsson, E. B. ve Schutte, N. S. (2007). The efficacy problem solving therapy in reducing mental and physical health problems. A metaanalysis. Clinical Psychological Review, 27, 46-57.

Markman, H.J., Floyd, J.F., Stanley, S.M. \& Storaasli, R.D. (1988). Prevention of marital distress. A longitudinal investigation. Journal of Consulting and Clinical Psychology, 56 (2), 210-217.

Markman, H. J., Stanley, S. M., Jenkins, N. H., Petrella, J. N. ve Wadsworth, M. E. (2006). Preventive education: Distinctives and directions. Journal of Cognitive Psychotherapy: An International Quarterly, 20(4), 411-433

Maughan, D. R., Christiansen, E., Jenson, W. R., Olympia, D. ve Clark, E. (2005). Behavioral parent training as a treatment for externalizing behaviors and disruptive behavior disorders: A meta-analysis. School Psychology Review, 34(3), 267-286.

McMurran, M., Egan, V., Blair, M. ve Richardson, C. (2001). The relationship between social problem-solving and personality disorder. Personality and Individual Differences, 30, 517-524.

Minuchin, S. (1974). Families and family therapy. Cambridge MA: Harvard University Press.

Möller-Leimkühler, A.M. (2002). Barriers to help-seeking by men: A review of sociocultural and clinical literature with particular reference to depression. Journal of Affective Disorders, 71, 1-9.

Nixon, R. D. V. (2002). Treatment of behavior problems in preschoolers: A review of parent training programs. Clinical Psychological Review, 22, 525-546.

O'Brien, M. P., Zinberg, J. L., Lorena, H., Rudd, A., Kopelowicz, A., Daley M., Bearden, C. E. ve Cannon, T. D. (2009). Family problem solving interactions and 6-month symptomatic and functional outcomes in youth at ultra-high risk for psychosis and with recent onset psychotic symptoms: A longitudinal study. Schizophrenia Research, 107, 198-205.

Pihet, S., Bodenmann, G., Cina, A., Widmer, K. ve Shantinath, S. (2007). Can prevention of marital distress improve well-bsaeing? A 1 year longitudinal study. Clinical Psychology and Psychotherapy, 14, 79-88.

Robles, T. F. ve Kiecolt-Glaser, J.K. (2003). The physiology of marriage: path ways to health. Physiology \& Behavior, 79, 409-416. 
Bilişsel Davranışçı Yaklaşım Temelli Psiko-eğitim Programının Anneler Üzerindeki Etkililiğinin İncelenmesi

Rodrigo, M. J., Maiquez, M. L., Correa, A. D., Martin, J. C. ve Rodriguez, G. (2006). Outcome evaluation of a community center-based program for mothers at high psychosocial risk. Child Abuse \& Neglect, 30, 1049-1064.

Sardoğan, M.E. ve Karahan, T.F. (2005). Evli bireylere yönelik bir insan ilişkileri beceri eğitimi programının evli bireylerin evlilik uyum düzeylerine etkisi. Ankara Üniversitesi Ĕ̆itim Bilimleri Fakültesi Dergisi, 38(2), 89-102.

Satir, V. (1981). Family systems and approaches to family therapy. İçinde G.D. Ericson, T.P. Hogan (Ed.). Family Therapy: An Introduction to Theory and Technique (2nd ed.), (pp. 40-52). California: Brooks/Cole Publishing Company. Seligman, (2001). Systems, strategies, and skills of counseling and psychotherapy (1st ed). New Jersey. Prentice-Hall.

Steinglass, P. (1987). A systems view of family interaction and psychopathology. İçinde T. Jacob (Ed.), Family interaction and psychopathology: theories, methods, and findings (1 ${ }^{\text {st }}$ ed), (pp. 25-66). New York and London: Plenum Press.

Tezer, E. (1986). Evli eşler arasındaki çatışma davranışları: Algılama ve doyum. Yayınlanmamış Doktora Tezi, Hacettepe Üniversitesi, Ankara, Türkiye.

Türkiye İstatistik Kurumu (TÜİK), (2010). İş istatistikleri. Temmuz 2011'de http:/ / www.tuik.gov.tr/ adresinden elde edildi.

United Nations Statistics Division (UNSD), (2010). The world's women 2010: Trends and statistics. Temmuz 2011'de http://unstats.un.org/ adresinden elde edildi.

Waite, L. J., Luo, Y. ve Lewin, A. C. (2009). Marital happiness and marital stability: consequences for psychological well-being. Social Science Research, 38, 201-212.

World Federation for Mental Health [WFMH], (2010). The great push: investing in mental health. Temmuz 2011'de http://wfmh.com adresinden elde edilmiştir. 